A special side excursion had becn arranged for those members of the party specially interested in mining and metaliurgy. These, as the guests of the Copper Queen Co., left the main body at El Paso, on the frontier, and travelled west to Bisbee (Arizona), Cananea (Sonora, Mexico), Douglas (Arizona), and Nacozari (Sonora), visiting the various copper mines and smelting works at these places, and then rejoining the main party.

Although by that time the rainy season was supposed to be nearly over, the members taking part in the northern excursion also had some experience of the difficulties caused by "wash-outs," \&c., in a country like Mexico, and at several places the programme had to be curtailed owing to delays to the trains.

The last event of all was an excursion of a week's duration made by a party of sixty or seventy members, who left Mexico City on October 6 to visit the Isthmus of Tehuantepec as the guests of Sir Weetman Pearson, whose firm have consiructed the railway and docks which now serve as a means of communication between the Atlantic and Pacific coasts of the Republic at its narrowest part.

As has been indicated, the members of the congress were everywhere received with the greatest hospitality, on the excursions as well as in the capital. One of the many social functions during the meeting may perhaps be allowed special mention; this was the reception of the members by President and Madame Diaz in the famous Palace of Chapultepec ("The Hill of the Grasshopper") After having been welcomed by their hosts, they spent some time admiring the magnificent views from the upper terraces, including the city and the distant snow-capped peaks of Popocatapetl and Jxtaccihuatl. In the evening they were entertained to a banquet on the lower terrace they had been invited "to tea," but tea appeared to bc the one thing which was not provided.

The meeting of the congress was in all respects a very great success, and for this the Mexican officials, both of the Government and of the congress, deserve the highest praise. While all did well, it is no disparagement to the others to say that thanks are specially due to the general secretary, Mr. Ordonez, for the admirable manner in which he filled that responsible and trying position.

\section{METEOROLOCICHL NOTES.}

THE frequency of thunderstorms in relation to the sulfspot period is discussed by Dr. Aksel $S$. Steen in at reprint from the "Hann-Band der meteorologischen Zeitschrift." The author has dealt with data from Norway, Sweden, and Denmark, using material from twenty, twenty-eight, and eight stations in each country respectively, extending from the years 1873 to 1003 . The result of the inquiry is to show that the curves for the frequency at each of these regions have maxima at about the times of the sun-spot maxima, and minima at about sun-spot minima, but underlying this variation one of half the period is apparent. In combining the results of all the three stations, the curve still shows the elfeven-year variation with the change of shorter duration.

Dr. Steen suggests that similar observations covering orher regions should be discussed to see if they exhibit similar changes.

Another reprint from the same "Hann-Band" deals with the yearly air movement as determined by registering anemometers over some European stations, and is contributed by Dr. Felix M. Exner. The author discusses, in the first instance, wind observations made at Pola, Vienna, Potsdam, Zurich, Santis, Bremen, Obir, and Sonnblick.

His method of analysis is to calculate the resultant of the sixteen wind directions and to reduce them to north and west components. Thus winds from the west or east were considered as $+\mathrm{W}$ and $-\mathrm{IV}$, while those from the north or south were treated as $+N$ and $-N$. The resulting west and north components were then determined for each year, and expressed in units of hundreds of kilometres.

It is shown that, according to the sign of the west component, with the exception of Pola, all the stations are under the influence of the general air circulation from the west. In the case of the north component, such a No. 1933, VOL. 757 general result is not obtained. It is positive in Vienna, Zurich, and on the Sonnblick, sometimes positive in Pola and on the Obir, but generally negative. Local causes are suggested as to the origin of some of these results. At Potsdam, Bremen, and Santis the north component is negative, and these are considered as good undisturbed stations.

The proportion of the north to the west component is generally less than $I$ or $-I$, so that the resulting wind direction is from the S.S.W. The author next investigates the atmospheric pressure values in relation to these variations of wind direction and velocity, and concludes that the yearly northern pressure gradients vary considerably, and that these changes harmonise in a satisfactory manne with those of the air movements. The paper is accompanied by numerous sets of curves showing the similarity of the variations discussed.

Prof. H. Hildebrand Hildebrandsson contributes an important article in the same "Hann-Band" on the circulation of the upper layers of air above the maximum of the North Atlantic Ocean. Prof. Hildebrandsson refers to the recent important researches of Messrs. Rotch, Teisserenc de Bort, Hergesell, Clayton, and Maurice, and, finally, says that "our results concerning the general circulation of the atmosphere are verified by direct observations made by means of kite flying and free balloons."

The article is accompanied by two very instructive maps showing for summer and winter the mean direction of motion of the upper clouds in relation to the isobars. These charts bring out ciearly the east-to-west motion throughout the year of the upper currents over the equator and the west-to-east motion in the higher latitudes, indicating an enormous whirl of air round the pole.

In another reprint from the same source we have a discussion of two long series of evaporation measures made at the Kremsmünster Observatory; this discussion was undertaken by Prof. P. Franz Schwab, director of the obscrvatory. The observations divide themselves naturally into two groups, the first- series being. commenced in $182 \mathrm{I}$ and ending in 1845 , while the second began in 188.5 and is being continued to-day.

Prof. Schwab in a series of tables brings together the monthly and yearly values, and treats the daily and annual variations at some length, comparing the latter with results obtained at numerous other stations.

Dietrich Reimer (Berlin, 1905) has published an excellent mean rainfall map of Germany, with explanatory notes, which have been prepared by Prof. G. Hellmann. This map which is on a scale of $1: 1,800,000$, shows the distribution of the mean yearly rainfall over the land from 3000 stations, the observations from which the values were derived extending from 1893 to 1902 . To gain some ide: of the distribution of these stations, it may be stated that Prussia and the other North German States are represented by 2341 stations, Bayern by 252 , Saxony by 166 Württemberg by 90 , Baden by 49 , Hessen by 32 , and ElsassLothringen by 7 o. Thus in North Germany there is one station for cvery 163 square kilometres, and one for every 295 square kilometres in South fiermany. The map gives twelve different shades (ten in blue and two in yellow), and shows at a glance the geographical distribution over this part of Europe.

In the introduction in the meteorological report for the year ro03, published by the Survey Department, Finance Ministry, Cairo, we read that "The meteorology series for Abbassia closes with the end of 1903 , and that for Helwan begins from January $1,1904 . "$ In this volume we have in the appendices the first instalment of a few discussions re lating to the data collected at Abassia since it was started. These are guite brief, but the discussions will no doubt serve to indicate points for future study. Thus, for instance, the large differences in evaporation recorded at the observatory are well worth careful study, and they will no doubt be found to be closely associated with changes of other meteorological elements when a longer series of observations becomes available. The present report includes all the meteorological data collected at the observatory and various out-stations, together with daily readings of the various river-gauges situated at different parts of the Nile. The reader's attention should, hotvever, be 
directed to the rather long list of errata for this volume given at the beginning of the report.

In vol. xx., part $i$, , of the Indian Meteorological Memoirs, we have the first instalment of what we hope will be a series of valuable contributions to the meteorology of the upper air in India.

Up to the present time Indian meteorologists have been considerably hampered in dealing with the air circulation over India, as the only fact which existed from which they could form any idea of the air currents in the upper strata was the movement of clouds.

A systematic investigation of the upper air began, however, last year, and the chief points of the inquiry in the first instance are to determine the distinctive features of the monsoon currents as regards their depths, temperature and velocity gradients, and humidity distributions.

In the present memoir, written by Mr. F. H. Field, deputy meteorologist, and published under the direction of Dr. G. T. Walker, reference is naturally made more to the instruments employed and the methods of using them than to the observations recorded. Advantage has naturally been taken of the experience of other workers in the field, and the English, American, and German systems have all received careful study.

The greatest height as yet reached is 1380 metres, and some details are given as to the records of the self-registering instruments employed during the flights made in August and September last when this elevation was reached.

The importance of this method of investigation will at once be seen when it is noted that accurate measurements can be made of the elevation of the stratum of saturated air day by day. Thus we read that " a nearly saturated stratum of air from the sea extended from the ground surface (about io metres above the sea) upwards to a level which rose from 500 metres on August 27 through 800 metres on August 28 to 1130 metres on August 31. From that day onward till September 9, its jimiting height was not reached by the kite, but probably exceeded rooo metres; its upper limit fell again by September 12 to 600 metres.'

The reader is referred to the memoir itself for details regarding the apparatus used and the various interesting meteorological curves given relative to the numerous fights made.

\section{FURTHER RESULTS OF THE JESUP} NORTH PACIFIC EXPEDITION.

THE recently published memoirs of the Jesup North Pacific Expedition maintain the excellence both as to matter and illustration of the previous volumes. $\mathrm{Mr}$. Swanton ${ }^{1}$ gives an account of the religious ideas and social organisation of the Haida Indians, who, to the number of about 6oo, occupy the towns of Skidegate and Masset, Queen Charlotte Islands. The whole Haida stock is divided into two "clans," the Raven clan and the Eagle clan, the significance of the division being purely social. Each is strictly exogamic, a Raven man being compelled to marry an Eagle woman, and an Eagle man a Raven woman, while the children always belong to their mother's clan. A man of the Raven clan was reckoned in that clan wherever he might go, and the Ravens among whom he settled were his uncles, elder and younger brothers, sisters and nephews. The members of the opposite clan were frequently considered downright enemies. "Even husbands and wives did not hesitate to betray each other to death in the interest of their own families. At times it almost appears as if each marriage were an alliance between opposing tribes; a man begetting offspring rather for his wife than for himself, and being inclined to see his real descendants rather in his sister's children than in his own " (p. 62),

The Raven and the Eagle do not seem to have been deities or deified ancestors. "A West Coast man said that the people sometimes left food for a raven on the beach, and, when it got near them, told it to give them something." Another man, however, said "they did not sacri-

1 "Contributions tn the Ethnology of the Haida." By J. R. Swanton. Jesup North Pacific Expedition, vol. v. part i., 1905. fice to it or pray to it, because it stole too much as it was." And although Eagle was called "grandfather" by men of the Eagle clan, as Raven was called " grandfather" by the Ravens, this was not because either was regarded as a direct ancestor, "but because they had been prominent heroes of the mythical period, and belonged respectively to the Eagle and Raven clans."

The clans were divided into an indefinite number of "families," and the "family" is the fundamental unit in Haida society. These usually take their names from towns or camping grounds, and are simply local groups. The "family" was divided into households, and there were thus house chiefs, family chiefs, and town chiefs.

The families had certain prerogatives which they guarded jealously, such as the right to use certain personal, house, and canoe names, and the right to wear certain objects or representations of objects, and to carve them upon their houses or property. "These latter I have called 'crests.' They were generally representations of animals; but trees, shells, and figures of objects used in daily life also occur. They were originally obtained from some supernatural being or by purchase from another family." The author is wise in refraining from the use of the word totem in this connection, for, as he justly remarks, "they have ... no proper totemic significance, their use being similar to that of the quarterings in heraldry, to mark the social position of the wearers" ; but the name " totem-pole" has crept in beneath the illustrations of the poles, carved with crests, placed on front of the houses (Plates i.-iii.).

The author is of opinion that the "crest system" was "rooted in religion," and that it may have developed from the "personal manitou" (p. 1 1 2).

The study of the Haida social organisation is of peculiar interest, since it is possible to view the conflict actually going on between the purely maternal family organisation and the paternal property laws, and the complexities resulting therefrom. It is to be hoped that future observers will apply Dr. Rivers's genealogical methods to the investigation of the sociology of these and other American tribes, as it would be sure to yield important results. This method, however, was not published in time for Mr. Swanton to utilise it.

Turning to religious beliefs, the Haida world is peopled with supernatural beings of the air, sea, and land; the sun is of comparative unimportance, and the moon belongs to the Raven clan. The chief of the Haida deities is Power-of-the-Shining-Heavens, who gives "power" to all things; he is prayed to in sickness or sorrow, and the clouds are his blankets. Owing to the character of the country, the entanglement of land and sea, and the impenetrable nature of the interior, all communication must be by sea, and the supernatural beings of the sea have thus attained an exaggerated importance; but a supernatural being can be destroyed " by cutting its body in two and throwing a whetstone between the severed portions. In their endeavours to coalesce, the two parts then grind themselves to nothing."

The shaman was "possessed" by a supernatural being, and became for the time being the supernatural being himself. The calling was generally hereditary in the family, descending from maternal uncle to nephew, but the youth had to qualify himself by training. "Spirits would come and look around a village to find "one who was clean" through whom they would act." To become "clean" a man had to abstain from food for a long time. A spirit once, looking through the smoke-hole of a house, saw a youth lying almost dead, "but he was so 'clean' that he looked transparent 'like glass.' So the spirit entered him."

The volume, which is profusely illustrated, deals also with secret societies and potlatches, or the ceremonial giving away of property, and contains nearly 200 Haida stories.

The third and last part of the volume of the $\mathrm{K}$ wakiut texts ${ }^{1}$ collected by Dr. Boas and Mr. Hunt is now published. These folk-tales form a mine of treasures for the folklorist, and are especially valuable as giving unbiased and unconscious evidence concerning custom and belief.

1 "Kwakiutl Texts." Ry Franz Boas and George Hunt. Jesup Nortb Pacific Expedition, vol. iii. part iii., r905. 